\title{
KEANEKARAGAMAN JENIS BURUNG DIURNAL DI KAWASANEKOWISATA RIAM SOLANG KECAMATAN SENGAH TEMILA KABUPATEN LANDAK PROVINSI KALIMANTAN BARAT
}

\author{
Species Diversity of Diurnal Birds In Riam Solang of Sengah Temila District Landak Regency \\ west kalimantan Province
}

\author{
Yosef joni, Erianto, Sarma Siahaan \\ Fakultas Kehutanan Universitas Tanjungpura Jalan Imam Bonjol Pontianak 78124 \\ Email : yosefjoni1023@gmail.com
}

\begin{abstract}
Riam Solang tourism object is one of the natura attractions in Senakin Village Sengah Temila district Landak Regency with area 16,192.98 $\left(161 \mathrm{~km}^{2}\right)$. Birds are one component of the ecosystem that has an importan role in supporting the life cycle of an organism. This situation can be seen from the food chains and webs of life that make up living systems with other ecosystem components such as plants with insects The purpose of this study was to obtain data on the diversity of diurnal bird species in the Riam Solang ecotourism Sengah Temila, District Landak Regency West Kalimantan Province. The results of the study are expected to be able to provide scientific data and information on the diversity of diurnal bird species in the Riam Solang canyon ecotourism Sengah Temila, District Landak Regency West Kalimantan Province. The results of diversity diurnal bird species in Riam Solang that in first path the diversity index was 2.8695, in the second path the diversity index was 2.7129, in the third path the diversity index was 2.6944, and in the fourth path the diversity index is 2.7754 . While the results of type evenness index in the frist lane was 0,9018, in the second path the evenness index is 0,8911, in the third path evenness index is 0,8994, and in the fourth path evenness index is 0,8979 . The results of the type wealth index found at the study site are in first path the wealth type index is 4,6656, in the second path the wealth index 4,2386, in the third path wealth index 4,1318 , and in the fourth path the wealth type index is 4,4504.
\end{abstract}

Keyword: Diurnal Bird, Diversity, Riam Solang, Species

\section{PENDAHULUAN}

Kabupaten Landak memiliki sumberdaya alam, baik flora dan fauna maupun gejala alam yang menyertainya, serta panorama alam yang semuanya itu merupakan kekayaan alam yang potensial untuk dikembangkan contohnya objek wisata Riam Solang. Riam solang merupakan salah satu objek wisata alam yang terletak di Desa Senakin Kecamatan Sengah Temila Kabupaten Landak dengan luas wilayah \pm 16.192 .98 (161 km2). Objek wisata
Riam Solang juga memiliki berbagai macam jenis burung kondisi keanekaragaman jenis burung dapat menjadi tambahan nilai daya tarik objek wisata Riam Solang. Tujuan penelitian yaitu untuk mendapatkan data komposisi burung diurnal di Kawasan Ekowsata Riam Solang Kecamatan Sengah Temila Kabupaten Landak Kalimantan Barat. Hasil penelitian ini diharapkan mampu menyediakan data dan informasi ilmiah mengenai keanekaragaman dan kelimpahan jenis 
burung diurnal pada Kawasan Ekowsata Riam Solang Kecamatan Sengah Temila Kabupaten Landak Kabupaten Kalimantan Barat.

\section{METODE PENELITIAN}

Penelitian dilakukan di Kawasan Ekowisata Riam Solang Kecamatan Sengah Temila Kabupaten Landak Kalimantan Barat dan dilakukan selama 14 hari di lapangan. Luas lokasi penelitian yang diambil di sekitar areal air terjun Riam Solang \pm 20 hektar dan dibagi dalam 4 jalur pengamatan dengan 3 kali pengulangan setiap jalur pengamatan. Metode yang digunakan yaitu metode IPA (Index Ponctualle de'Abundance) yang ditempatkan secara Purposive, metode ini adalah pengabungan antara metode point count dan metode transek. Pelaksanaan pengamatan dilakukan pada 4 (empat) jalur pengamatan yang terpisah dengan 3 (tiga) kali pengulangan. Pengamatannya dengan cara diam pada titik tertentu dengan durasi waktu \pm 20 menit kemudian berjalan lagi dan berhenti di titik tertentu lagi lalu mencatat perjumpaan terhadap burung dalam waktu tertentu. Radius pengamatan untuk setiap titik sejauh 50 meter (25 meter kekiri dan 25 meter kekanan) dengan jarak antar titik 200 meter, panjang transek $1.050 \mathrm{~km}$. waktu pengamatan pagi pukul $05.00-09.00$ WIB dan sore pukul 14.00 -17.30 WIB.

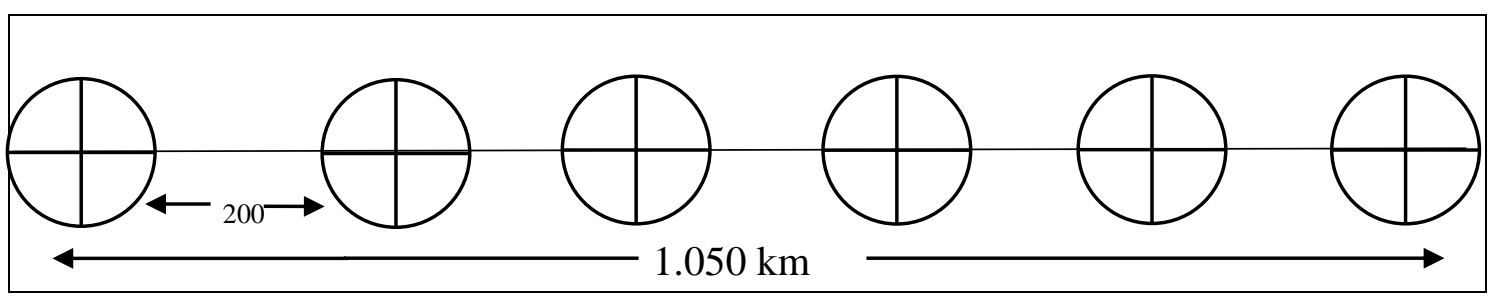

Gambar 1. Metode Jalur Pengamatan Burung Diurnal (Diurnal Bird Observation method)

Analisis data yang dilakukan yaitu indeks dominasi, indeks keanekaragaman jenis, indeks kemerataan jenis, dan indeks kekayaan jenis.

\section{HASIL DAN PEMBAHASAN}

Berdasarkan hasil penelitian di Riam Solang Kecamatan Sengah Temila Kabupaten Landak ditemukan 24 jenis burung diurnal dengan jumlah 1.306 individu, terdiri atas 13 famili. Jalur 1 terdapat 24 jenis burung dengan jumlah 415 individu yang termasuk dalam 13

famili, Jalur 2 terdapat 21 jenis burung dengan jumlah 336 individu yang termasuk dalam 10 famili, Jalur 3 terdapat 20 jenis burung dengan jumlah individu 398 yang termasuk dalam 11 famili, sedangkan pada jalur 4 terdapat 22 jenis burung dengan jumlah 257 individu yang termasuk dalam 11 famili.

Berdasarkan hasil pengamatan yang dilakukan pada lokasi penelitian terdapat 2 jenis burung yang masuk dalam status perlindungan berdasarkan 
Peraturan Mentri Lingkungan Hidup dan Kehutanan (PMLHK) No P.106 tahun 2018 perubahan kedua tentang Jenis Tumbuhan dan Satwa yang
Dilindungi. Hasil pengamatan jumlah individu setiap family pada setiap jalur pengamatan terdapat pada gambar 2 .

\section{Jumlah Individu Famili Setiap Jalur Pengamatan}

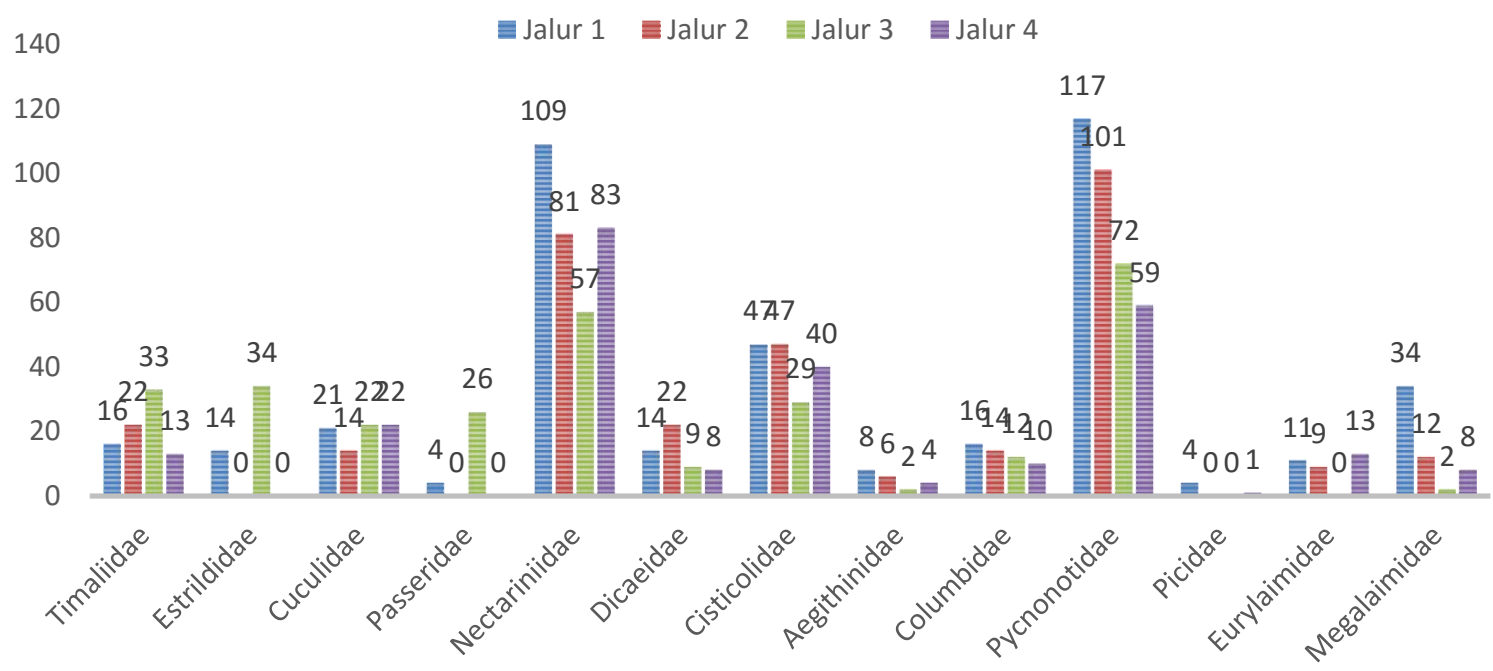

Gambar 2. Jumlah Individu Setiap Famili pada Setiap Jalur Pengamatan (The Number of Individuals Family on Each Observation Line).

\section{Pengamatan pada Jalur Pertama}

Jalur pertama merupakan hutan sekunder dengan kerapatan vegetasi sedang, oleh karena itu burung dapat mencari makan dan hidup pada daerah tersebut. Berdasarkan hasil pengamatan pada jalur pertama terdapat 24 jenis burung dengan jumlah 415 individu yang termasuk dalam 13 famili. Jumlah individu setiap famili pada jalur pengamatan dapat disajikan pada gambar 3 .

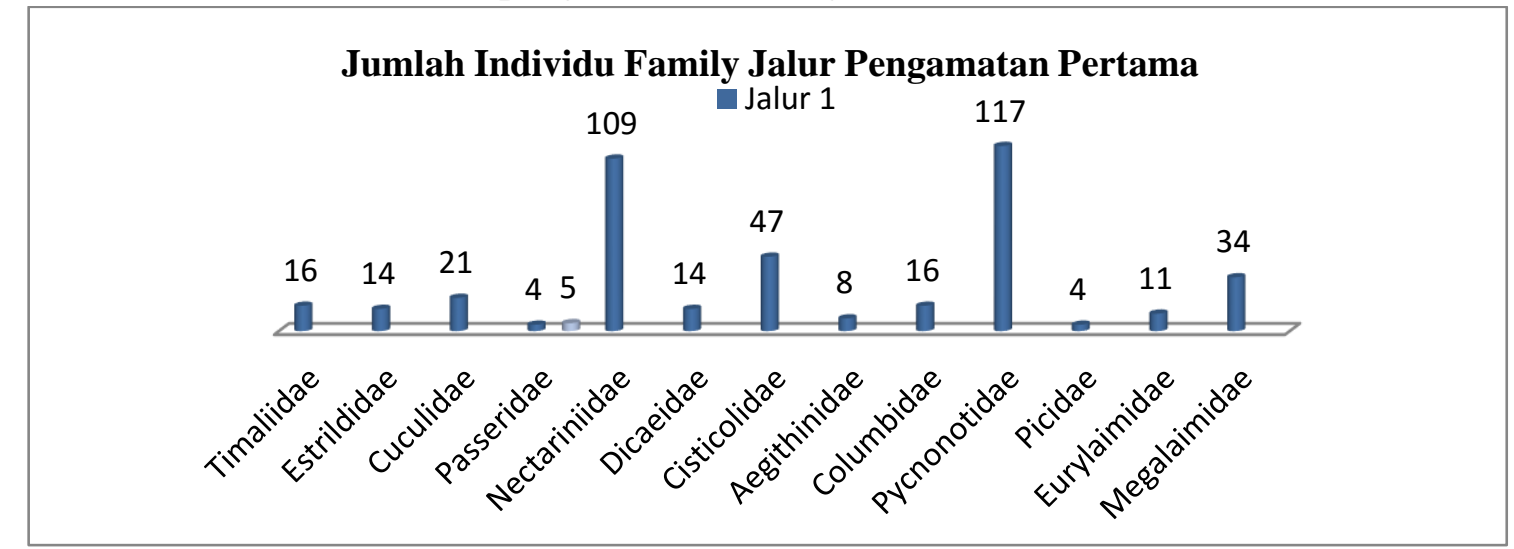

Gambar 3. Jumlah Individu setiap Famili pada Jalur Pertama (The number of Individuals Family in the First Lane). 
Berdasarkan hasil pengamatan yang dilakukan pada jalur pertama yaitu terdapat jenis burung yang mendominasi yaitu seperti Merbah mata-merah (Pycnonotus brunneus) dengan 60 individu, Merbah cerukcuk(Pycnonotus goiavier) sebanyak 57 individu, Burung-madu polos(Anthreptes simplex) sebanyak 37 individu, dan Pijantung Kecil(Arachnothera longirostra) sebanyak 36 individu. Hasil pengamatan pada jalur pertama tercatat 2 jenis burung yang dilindungi berdasarkan Peraturan Mentri Lingkungan Hidup dan Kehutanan (PMLHK) No P.106 tahun 2018 yaitu burung Pelatuk Kelabu-Sulawesi (Mulleripicus fulvus) dan burung Takur Tutut (Megalaima rafflesii).

\section{Pengamatan pada Jalur Kedua}

Jalur kedua merupakan hutan sekunder dengan kerapatan vegetasinya sedang, sehingga satwa khususnya burung mencari makan dan menjadikannya tempat hidup dan berkembang biak. Sebagai salah satu komponen ekosistem, burung mempunyai hubungan timbal balik dan saling ketergantungan dengan lingkungan. Atas dasar peran ini maka kehadiran burung dalam suatu ekosistem perlu dipertahankan (Arumasari 1989). Dari hasil pengamatan yang dilakukan pada jalur kedua dengan tiga kali pengulangan terdapat 21 jenis burung dengan jumlah 336 individu yang termasuk dalam 10 famili. Jumlah individu setiap famili pada jalur kedua dapat disajikan pada gambar 4.

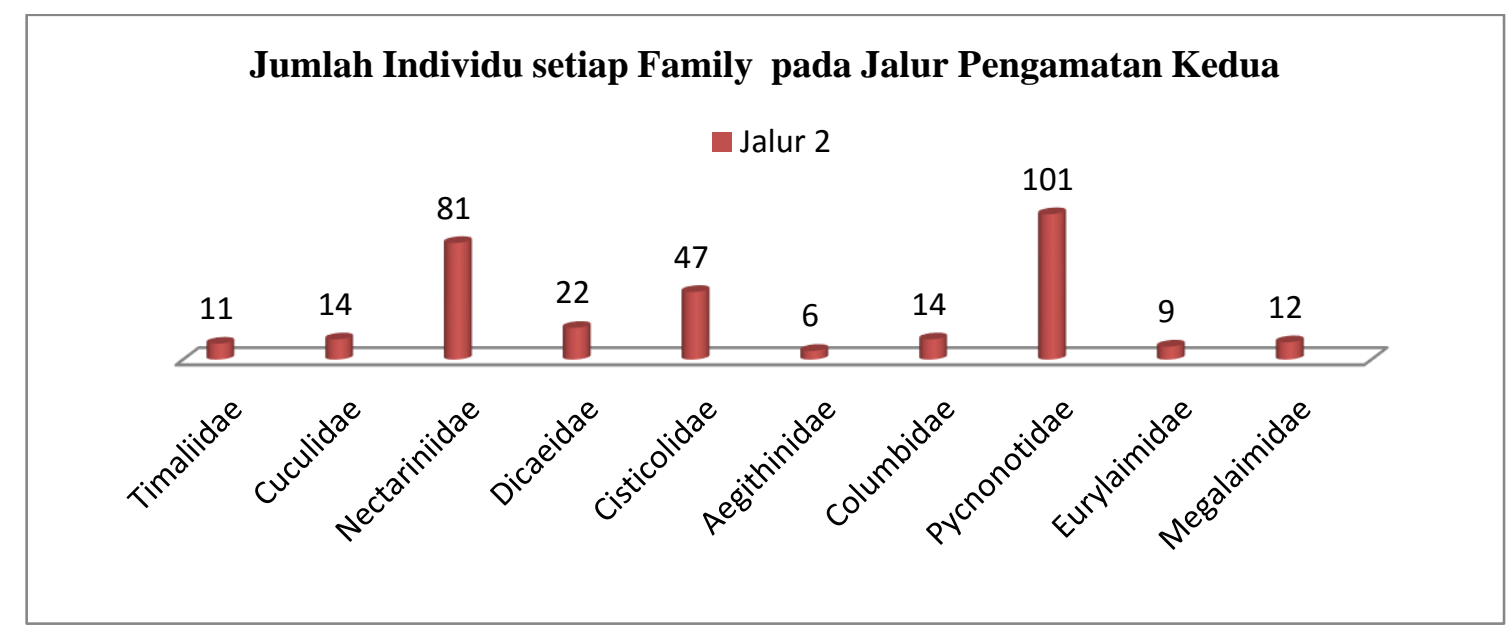

Gambar 4. Jumlah Individu setiap Famili pada Jalur Kedua (The number of individuals family in the second lane).

Hasil pengamatan pada jalur kedua terdapat jenis burung yang sering dijumpai pada jalur pengamaan yaitu burung Merbah cerukcuk (Pycnonotus goiavier) sebanyak 61 individu, Merbah mata-merah (Pycnonotus brunneus) dengan 46 individu. Tercatat 1 jenis burung yang dilindungi berdasarkan Peraturan Mentri Lingkungan Hidup dan Kehutanan (PMLHK) No P.106 
tahun 2018 yaitu burung Takur Tutut (Megalaima rafflesii).

\section{Pengamatan pada Jalur Ketiga}

Kondisi vegetasi yang berada pada lokasi penelitian yaitu hutan sekunder yang bisa menjadi tempat pencarian makan untuk satwa khususnya burung.
Berdasarkan hasil pengamatan jalur ketiga dengan tiga kali pengulangan terdapat 20 jenis burung dengan jumlah pada jalur 3 yaitu 398 individu yang termasuk dalam 11 famili. Jumlah individu setiap famili pada jalur ketiga dapat disajikan pada gambar 5.

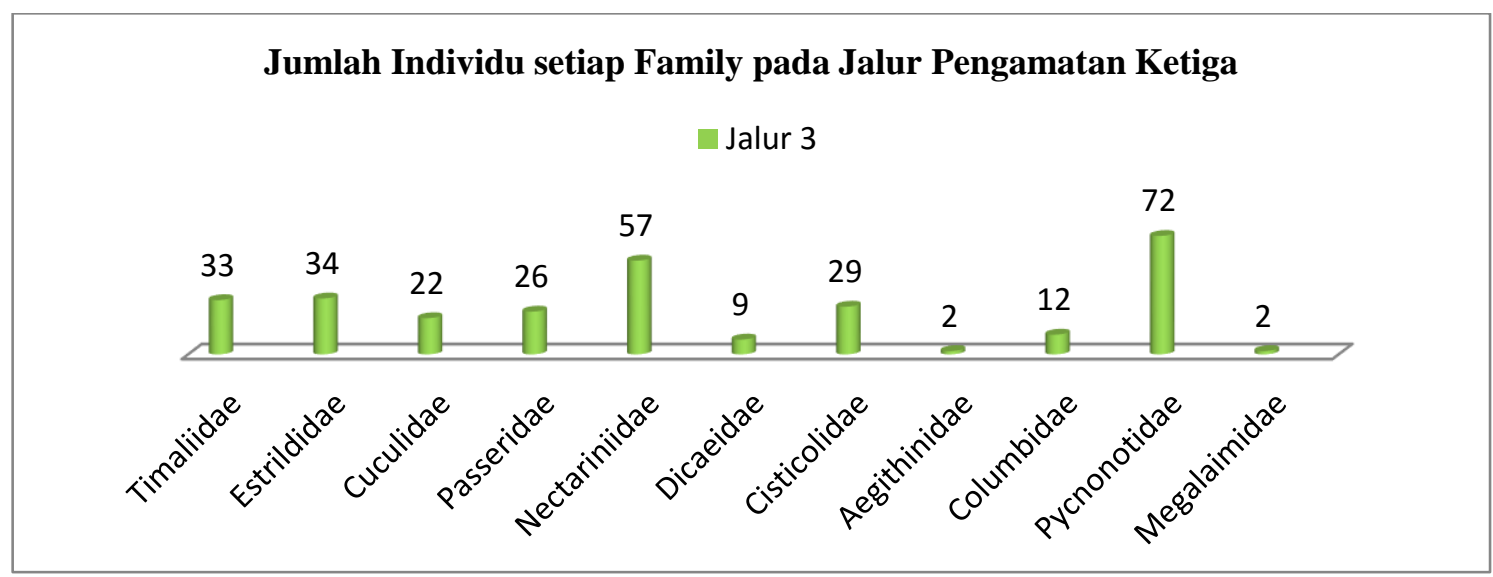

Gambar 5. Jumlah Individu setiap Famili pada Jalur Ketiga (The number of individuals family in the third lane).

Hasil pengamatan yang dilakukan pada jalur ketiga terdapat jenis burung yang sering dijumpai adalah burung Merbah cerukcuk (Pycnonotus goiavier) sebanyak 42 individu, burung Bondol Kalimantan (Lonchura fuscans) sebanyak 34 individu, Merbah matamerah (Pycnonotus brunneus) dengan 30 individu, Burung-madu polos (Anthreptes simplex) sebanyak 27 individu. Tercatat 1 jenis burung yang dilindungi berdasarkan Peraturan Mentri Lingkungan Hidup dan Kehutanan (PMLHK) No P.106 tahun
2018 yaitu burung Takur Tutut (Megalaima rafflesii).

\section{Pengamatan pada Jalur Keempat}

Kondisi vegetasi yang terdapat pada lokasi penelitian merupakan kondisi hutan sekunder memudahkan untuk satwa khususnya burung untuk mencari makan dan menjadikan tempat untuk hidup. Dari hasil pengamatan jalur keempat dalam tiga kali pengulangan terdapat 22 jenis burung dengan jumlah 257 individu yang termasuk dalam 11 famili. Jumlah individu setiap famili pada jalur keempat dapat disajikan pada gambar 6 . 


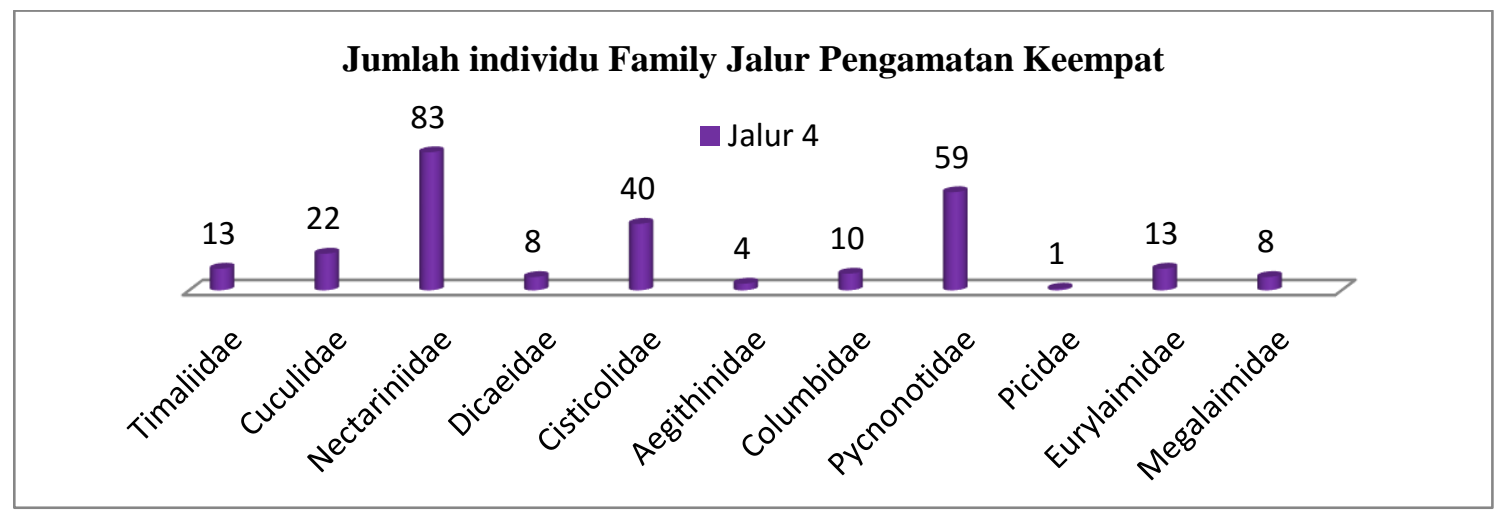

Gambar 6. Grafik Jumlah Individu setiap Family pada Jalur Pengamatan Keempat (The number ofindividuals family in the fourth lane)

Hasil pengamatan yang dilakukan pada jalur keempat terdapat jenis burung yang sering dijumpai yaitu burung Merbah mata-merah (Pycnonotus brunneus) 36 individu, burung Merbah cerukcuk (Pycnonotus goiavier) 29 individu, Burung-madu polos (Anthreptes simplex) sebanyak 29 individu, dan Burung-madu belukar (Chalcoparia singalensis) terdapat 21 individu. Tercatat 2 jenis burung yang dilindungi berdasarkan Peraturan Mentri Lingkungan Hidup dan Kehutanan (PMLHK) No P.106 tahun 2018 perubahan kedua tentang Jenis
Tumbuhan dan Satwa yang Dilindungi yaitu burung Pelatuk KelabuSulawesi(Mulleripicus fulvus) dan burung Takur Tutut (Megalaima rafflesii).

\section{Komposisi Jenis Burung Diurnal pada Setiap Jalur Pengamatan}

Karagaman Jenis burung pada areal pengamatan dapat diketahui dari hasil perhitungan Indeks Dominasi jenis, Indeks Keanekaragaman Jenis, dan Indeks Kemerataan Jenis dan Indeks Kekayaan Jenis. Hasil perhitungan indeks dapat dilihat pada tabel 7.

Tabel 6. Indeks Dominasi Jenis, Indeks Keanekaragaman Jenis, Indeks Kemerataan Jenis,Indeks Kekayaan Jenis. (Species Dominance Index, Species Diversiy Index, Species Evenness Index, Species Wealth Index).

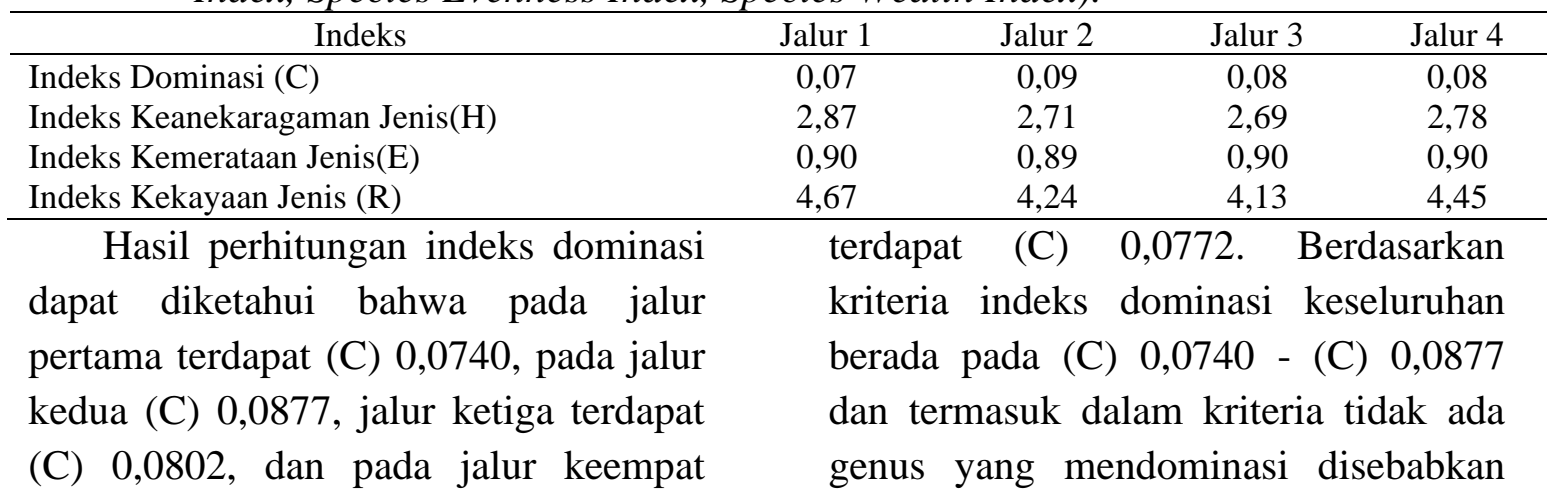


oleh adanya aktivitas masyarakat sehingga burung yang berada di lokasi penelitin merasa terganggu .

Dapat diketahui bahwa pada jalur pertama indeks keanekaragamannya yaitu $\quad(\bar{H}) \quad 2,8659, \quad$ indeks keanekaragaman pada jalur kedua adalah $\quad(\bar{H})$ 2,7129, indeks keanekaragaman pada jalur tiga yaitu $(\bar{H})$ 2,6944, dan pada jalur keempat indeks keanekaragaman adalah $(\bar{H})$ 2,7754. Oleh karena itu kondisi yang terdapat di lokasi penelitian yaitu hutan sekunder dan banyak aktivitas masyarakat yang memungkinkan untuk jenis-jenis burung yang tinggal dan menetap berkurang, Semakin tinggi indeks keanekaragaman jenis, maka semakin banyak jenis-jenis yang terdapat pada kawasan tersebut. Pada penelitian ini keanekaragaman jenis berada pada indeks antara 1 - 3 dan berdasarkan kriteria keanekaragaman menunjukan pada kelas sedang,

Hasil dari perhitungan menggunakan rumus indeks kemerataan jenis pada jalur pertama yaitu (E) 0,9018, indeks kemerataan jenis pada jalur kedua yaitu (E) 0,8911, indeks kemerataan jenis pada jalur ketiga ialah (E) 0,8994, dan indeks kemerataan pada jalur keempat adalah (E) 0,8979. Kemerataan jenis Pada penelitian ini berada pada indeks 0,21 - 1,00 dan berdasarkan kriteria yang terdapat dilokasi penelitan termasuk stabil dikarenakan oleh aktivitas masyarakat di sekitar lokasi penelitian dan komunitas ekologi atau wilayah yang di tempati oleh sekelompok individu burung yang bervegetasi sekunder memungkinkan tempat untuk mencari makan ataupun untuk tempat tinggalnya.

Dapat diketahui bahwa Pada jalur pertama indeks kekayaan jenisnya (R) 4,6656, jalur kedua indeks kekayaan jenisnya (R) 4,2386, sedangkan pada jalur ketiga indeks kekayaan jenisnya yaitu (R) 4,1318, dan indeks kekayaan jenisnya pada jalur keempat yaitu (D) 4,4504. Keseluruhan dari hasil pengamatan kekayaan jenis yang terdapat pada penelitian menunjukan indeks diatas 4 dan berdasarkan kriteria kekayaan jenis termasuk sangat tinggi dikarenakan lokasi tersebut adalah hutan sekunder yang biasanya terdapat banyak dijumpai jumlah individu burung yang mencari makan, menetap dan berkembang biak di daerah tersebut.

\section{Indeks Kesamaan Jenis}

Dari hasil pengamatan yang dilakukan pada masing-masing jalur dengan waktu pengamatan berbeda, terdapat kesamaan jenis burung yang di temukan pada setiap jalur pengamatan. Indeks kesamaan jenis dapat digunakan untuk melihat kesamaan jenis burung antara jalur. 
Tabel 7. Indeks kesamaan Jenis Burung Diurnal pada Semua Jalur Pengamatan (Index of Diurnal Bird Species Similarity in all observation Paths).

\begin{tabular}{lcccc}
\hline No & Jalur Pengamatan & $\begin{array}{c}\text { Jenis Yang Sama } \\
\text { C }\end{array}$ & $\begin{array}{c}\text { Jumlah Jenis } \\
(\mathrm{A}+\mathrm{B})\end{array}$ & $\begin{array}{c}\text { Indeks Kesamaan } \\
(2 \mathrm{C} / \mathrm{A}+\mathrm{B})\end{array}$ \\
\hline 1 & Jalur 1 - Jalur 2 & 21 & 45 & 93.33 \\
2 & Jalur 2 - Jalur 3 & 18 & 41 & 87.80 \\
3 & Jalur 3 - Jalur 4 & 19 & 42 & 90.48 \\
4 & jalur 4 - jalur 1 & 22 & 46 & 95.65 \\
\hline
\end{tabular}

Nilai indeks kesamaan jenis (IS) berkisar antara $0-100 \%$. Nilai indeks kesamaan makin dekat pada nilai $100 \%$, berarti dapat dikatakan bahwa komposisi relatif sama apabila makin dekat dengan nilai $0 \%$, maka menunjukan komposisi jenis berbeda. Hasil penelitian yang dilakukan terdapat nilai kesamaan jenisnya 87.80 - 95.65\% dengan demikian dapat digolongkan dalam kriteria komposisi relatif sama. Berdasarkan dari nilai indeks Kesamaan Jenis antara jalur 1 dan 2 tidak begitu jauh perbedaan dikarenakan lokasi hutan sekunder, jalur 2 dan 3 komposisi relatif sama dengan keadaan hutan sekunder, dan jalur 3 dan jalur 4 yang lokasi penelitan hutan sekunder juga sehingga nilai indeks kesamaan jenisnya tidak begitu jauh berbeda, dan jalur 4 dan 1 dengan komposisi relatif sama dengan jalur yang lain sehingga nilai komposisi tidak jauh berbeda karena lokasi penelitian hutan sekunder. Oleh karena itu jenis burung diurnal yang terdapat pada penelitian hampir sama setiap jalur pengamatan.

\section{Kesimpulan}

Kesimpulan penelitian ini ditemukan 24 jenis burung diurnal dengan jumlah 1.306 individu yang terdiri dari 13 famili. Indeks Dominasi jenis burung (C) pada jalur pertama 0,0740, jalur kedua 0,0877, jalur ketiga 0,0802, dan jalur keempat 0,0772 . Indeks keanekaragaman jenis $(\overline{\mathrm{H}})$. Pada jalur pertama adalah 2,8659, pada jalur kedua adalah 2,7129, sedangkan indeks keanekaragama pada jalur ketiga yaitu 2,6944, dan pada jalur keempat indeks keanekaragaman adalah 2,7754. Indeks Kemerataan jenis burung (E) pada jalur pertama yaitu 0,9018, indeks kemerataan jenis pada jalur kedua yaitu 0,8911, sedangkan indeks kemerataan jenis pada jalur ketiga adalah 0,8994, dan indeks kemerataan pada jalur keempat adalah 0,8979. Indeks kekayaan jenis (R) pada jalur pertama diperoleh 4,6656 , jalur kedua 4,2386, jalur ketiga yaitu 4,1318, dan pada jalur keempat yaitu 4,4504. kekayaan jenis yang terdapat pada penelitian masuk kedalam kriteria kekayaan jenis yang sangat tinggi dalam pengamatan di lapangan.

\section{Saran}

1. Perlu adanya perhatian dari pemerintah dalam upaya perlindungan seperti akses jalan serta pengelolaan Kawasan Ekowisata Riam Solang sehingga sumber daya alam yang terkandung di dalamnya tetap terjaga.

2. Diharapkan adanya penelitian lebih lanjut mengenai keanekaragaman jenis burung berkaitan dengan populasi individu jenis burung yang berada pada lokasi ekowisata riam solang. 
Terimakasih Kepada Kepala Desa Senakin dan masyarakat di sekitrarnya yang telah mengijinkan dan melancarkan saya dalam melakukan penelitian di Lokasi Ekowisata Riam Solang Kecamatan Sengah Temila Kabupaten Landak Provinsi Kalimantan Barat.

\section{DAFTAR PUSTAKA}

Alikodra HS. 2002. Pengelolaan Satwa Liar jilid 1.Departemen Pendidikan DanKebudayaan Direktorat Jendral Pendidikan Tinggi Riset Antar Universitas Ilmu Hayati Institut Pertanian Bogor.

MacKinnon JK, Phillips K, Bas VB. 2010. Seri Panduan Lapang BurungBurung Di Sumatera, Jawa, Bali Dan Kalimantan (Termasuk Sabah, Sarawak dan Brunai Darussalam).Pusat Panelitian Dan Pengembangan Biologi LIPI. Bogor.

Mardiastuti A, Hernowo JB, dan Mahmud A,2016. Penyebaran Burungburung Merandai Dicagar Alam Pulau Rambut. Media Konservasi, Volume III, No.4. Fakultas Kehutanan Intitut Pertanian Bogor, Bogor.

Partasasmita R. 2003. Ekologi Burung Pemakan Buah dan Perannya Sebagai Penyebar Biji. Makalah Falsafah Sains Program Pasca Sarjana Institut Pertanian Bogor. Bogor.

Partasasmita R, Mardiastuti A, Solihin DD, Widjajakusuma R, Prijono SN, da Ueda K. 2009. Komunitas Burung Pemakan Buah di Habitat Suksesi. Jurnal Biosfera 26(2):90-99.

PP No. 106. Tahun 2018 Tentang Jenis Tunbuhan dan Satwa yang Dilindung
Sawitri R, Mukhtar AS, dan Iskandar S. 2010. Status Konservasi Mamalia dan Burung di Taman Nasional Merbabu. Jurnal Penelitian Hutan Dan Konservasi Alam.

Sawitri Reny dan Iskandar Sofian. 2012. Keragaman Jenis Burung Di Taman Nasional Kepulauan Wakatobi Dan Taman Nasional Kepulauan Seribu. Jurnal Peneitian Hutan Dan Konservasi Alam. Vol. 9 No. 2 : 175-187, 2012.

Status Perlindungan Republik Indonesia (A.UU No.5 tahun 1990; B. PP No.7 tahun 1999)

Sukmantoro WM, Irham W, Novarino F, Hasudungan N, Kemp , M, Muchtar. 2007. Daftar Burung Indonesia no $2 . \quad$ Indonesia Ornithologist Union Bogor.

Undang-undang No. 41. Tahun 1999 Tentang Kehutanan.

Warsito H dan Bismark M. 2009. Penyebaran Dan Populasi Burung Paruh Bengkok Pada Beberapa Tipe Habitat di Papua. Jurnal Penelitian Hutan dan Konservasi Alam. 117(1):93-10

Welty, JC. 1982. The Life Of Bird. 3nd Edition.Saunders College Publishing.Philadelpphia: Philadelphia.

Wiens JA. 1989. The Ecology of Bird Communities (Volume 2, processes and Variations) Cambridgeshire: Cambridge University Press. 
Tabel 1. Daftar Jenis Burung yang Ditemukan di Lokasi Penelitian dan Status Perlindungannya (List of Brid Spesies Found at the Study Site and Protection Status)

\begin{tabular}{|c|c|c|c|c|c|c|c|c|c|c|c|c|}
\hline \multirow[t]{2}{*}{ No } & \multirow{2}{*}{ Nama Indonesia } & \multirow{2}{*}{$\begin{array}{c}\text { Nama } \\
\text { Inggris }\end{array}$} & \multirow{2}{*}{ Nama Latin } & \multirow{2}{*}{ Family } & \multicolumn{4}{|c|}{ Line transec } & \multicolumn{4}{|c|}{ Status perlindungan } \\
\hline & & & & & 1 & 2 & 3 & 4 & CITES & IUCN & $\mathbf{R I}$ & End \\
\hline 1 & Asi topi-sisik & Scaly-crowned Babbler & Malacopteron cinereum & Timaliidae & 9 & 15 & 25 & 7 & & $\mathrm{LC}$ & & \\
\hline 2 & Bondol kalimantan & Dusky Munia & Lonchura fuscans & Estrildidae & 14 & 0 & 34 & 0 & & $\mathrm{LC}$ & & \\
\hline 3 & Bubut besar & Greater Coucal & Centropus sinensis & Cuculidae & 9 & 5 & 12 & 2 & & $\mathrm{LC}$ & & \\
\hline 4 & Burung-gereja erasia & Eurasian Tree Sparrow & Passer montanus & Passeridae & 4 & 0 & 26 & 0 & & $\mathrm{LC}$ & & \\
\hline 5 & Burung-madu belukar & Ruby-cheeked Sunbird & Chalcoparia singalensis & Nectariniidae & 19 & 10 & 11 & 21 & & $\mathrm{LC}$ & & \\
\hline 6 & Burung-madu polos & Plain Sunbird & Anthreptes simplex & Nectariniidae & 37 & 23 & 27 & 29 & & $\mathrm{LC}$ & & \\
\hline 7 & Burung-madu sepah-raja & Eastern Crimson Sunbird & Aethopyga siparaja & Nectariniidae & 12 & 15 & 3 & 10 & & $\mathrm{LC}$ & & \\
\hline 8 & Cabai bunga-api & Orange-bellied Flowerpecker & Dicaeum trigonostigma & Dicaeidae & 14 & 22 & 9 & 8 & & $\mathrm{LC}$ & & \\
\hline 9 & Cinenen kelabu & Red-headed Tailorbird & Orthotomus ruficeps & Cisticolidae & 5 & 7 & 0 & 8 & & $\mathrm{LC}$ & & \\
\hline 10 & Cinenen belukar & Dark-necked Tailorbird & Orthotomus atrogularis & Cisticolidae & 15 & 7 & 10 & 8 & & $\mathrm{LC}$ & & \\
\hline 11 & Cinenen merah & Rufous-tailed Tailorbird & Orthotomus sericeus & Cisticolidae & 27 & 33 & 19 & 24 & & $\mathrm{LC}$ & & \\
\hline 12 & Cipoh kacat & Common Iora & Aegithina tiphia & Aegithinidae & 8 & 6 & 2 & 4 & & $\mathrm{LC}$ & & \\
\hline 13 & Delimukan zamrud & Emerald Dove & Chalcophaps indica & Columbidae & 7 & 7 & 10 & 4 & & $\mathrm{LC}$ & & \\
\hline 14 & Merbah cerukcuk & Yellow-vented Bulbul & Pycnonotus goiavier & Pycnonotidae & 57 & 61 & 42 & 29 & & $\mathrm{LC}$ & & \\
\hline 15 & Merbah mata-merah & Red-eyed Bulbul & Pycnonotus brunneus & Pycnonotidae & 60 & 46 & 30 & 36 & & $\mathrm{LC}$ & & \\
\hline 16 & Pelatuk Kelabu-Sulawesi & Ashy Woodpecker & Mulleripicus fulvus & Picidae & 4 & 0 & 0 & 1 & & $\mathrm{LC}$ & P.106 & \\
\hline 17 & Pijantung besar & Long-billed Spiderhunter & Arachnothera robusta & Nectariniidae & 5 & 6 & 3 & 5 & & $\mathrm{LC}$ & & \\
\hline 18 & Pijantung Kecil & Little Spiderhunter & Arachnothera longirostra & Nectariniidae & 36 & 29 & 13 & 18 & & $\mathrm{LC}$ & & \\
\hline 19 & Sempur-hujan darat & Black-and-yellow Broadbill & Eurylaimus ochromalus & Eurylaimidae & 11 & 9 & 0 & 13 & & NT & & \\
\hline 20 & Takur tenggeret & Blue-eared Barbet & Psilopogon cyanotis & Megalaimidae & 12 & 6 & 0 & 3 & & $\mathrm{LC}$ & & \\
\hline 21 & Takur tutut & Red-crowned Barbet & Megalaima rafflesii & Megalaimidae & 22 & 6 & 2 & 5 & & NT & P.106 & \\
\hline 22 & Tekukur biasa & Spotted Dove & Streptopelia chinensis & Columbidae & 9 & 7 & 2 & 6 & & $\mathrm{LC}$ & & \\
\hline 23 & Tepus kaban & Black-throated Babbler & Stachyris nigricollis & Timaliidae & 7 & 7 & 8 & 6 & & NT & & \\
\hline \multirow[t]{3}{*}{24} & Wiwik kelabu & Plaintive Cuckoo & Cacomantis merulinus & Cuculidae & 12 & 9 & 10 & 10 & & $\mathrm{LC}$ & & \\
\hline & & Jumlah individu & & & 415 & 336 & 298 & 257 & & & & \\
\hline & & Jumlah jenis & & & 24 & 21 & 20 & 22 & & & & \\
\hline
\end{tabular}

Keterangan : P.106 = Dilindungi LC (Beresiko rendah), NT (Hampir terancam) 
Tabel 2. Daftar jenis burung yang terdapat pada jalur pertama dengan 3 kali pengulangan (List of brid spesies found in the first lane with 3 repetitions)

\begin{tabular}{|c|c|c|c|c|c|c|c|c|c|c|}
\hline No & Nama Indonesia & Nama Inggris & Nama Latin & Family & $\mathbf{N i}$ & $x^{-}$ & $\mathbf{C}$ & $\overline{\boldsymbol{H}}$ & $\mathbf{E}$ & $\mathbf{R}$ \\
\hline 1 & Asi topi-sisik & Scaly-crowned Babbler & Malacopteron cinereum & Timaliidae & 9 & 3 & 0.0005 & 0.0831 & 0.0261 & 4.6656 \\
\hline 2 & Bondol kalimantan & Dusky Munia & Lonchura fuscans & Estrildidae & 14 & 4.667 & 0.0011 & 0.1143 & 0.0360 & \\
\hline 3 & Bubut besar & Greater Coucal & Centropus sinensis & Cuculidae & 9 & 3 & 0.0005 & 0.0831 & 0.0261 & \\
\hline 4 & Burung-gereja erasia & Eurasian Tree Sparrow & Passer montanus & Passeridae & 4 & 1.333 & 0.0001 & 0.0447 & 0.0141 & \\
\hline 5 & Burung-madu belukar & Ruby-cheeked Sunbird & Chalcoparia singalensis & Nectariniidae & 19 & 6.333 & 0.0021 & 0.1412 & 0.0444 & \\
\hline 6 & Burung-madu polos & Plain Sunbird & Anthreptes simplex & Nectariniidae & 37 & 12.333 & 0.0079 & 0.2155 & 0.0678 & \\
\hline 7 & Burung-madu sepah-raja & Eastern Crimson Sunbird & Aethopyga siparaja & Nectariniidae & 12 & 4 & 0.0008 & 0.1025 & 0.0322 & 4.6656 \\
\hline 8 & Cabai bunga-api & Orange-bellied Flowerpecker & Dicaeum trigonostigma & Dicaeidae & 14 & 4.667 & 0.0011 & 0.1143 & 0.0360 & \\
\hline 9 & Cinenen kelabu & Red-headed Tailorbird & Orthotomus ruficeps & Cisticolidae & 5 & 1.667 & 0.0001 & 0.0532 & 0.0168 & \\
\hline 10 & Cinenen belukar & Dark-necked Tailorbird & Orthotomus atrogularis & Cisticolidae & 15 & 5 & 0.0013 & 0.1200 & 0.0378 & \\
\hline 11 & Cinenen merah & Rufous-tailed Tailorbird & Orthotomus sericeus & Cisticolidae & 27 & 9 & 0.0042 & 0.1778 & 0.0559 & \\
\hline 12 & Cipoh kacat & Common Iora & Aegithina tiphia & Aegithinidae & 8 & 2.667 & 0.0004 & 0.0761 & 0.0240 & \\
\hline 13 & Delimukan zamrud & Emerald Dove & Chalcophaps indica & Columbidae & 7 & 2.333 & 0.0003 & 0.0689 & 0.0217 & \\
\hline 14 & Merbah cerukcuk & Yellow-vented Bulbul & Pycnonotus goiavier & Pycnonotidae & 57 & 19 & 0.0189 & 0.2727 & 0.0858 & \\
\hline 15 & Merbah mata-merah & Red-eyed Bulbul & Pycnonotus brunneus & Pycnonotidae & 60 & 20 & 0.0209 & 0.2796 & 0.0880 & \\
\hline 16 & Pelatuk Kelabu-Sulawesi & Ashy Woodpecker & Mulleripicus fulvus & Picidae & 4 & 1.333 & 0.0001 & 0.0447 & 0.0141 & \\
\hline 17 & Pijantung besar & Long-billed Spiderhunter & Arachnothera robusta & Nectariniidae & 5 & 1.667 & 0.0001 & 0.0532 & 0.0168 & \\
\hline 18 & Pijantung Kecil & Little Spiderhunter & Arachnothera longirostra & Nectariniidae & 36 & 12 & 0.0074 & 0.2121 & 0.0667 & \\
\hline 19 & Sempur-hujan darat & Black-and-yellow Broadbill & Eurylaimus ochromalus & Eurylaimidae & 11 & 3.667 & 0.0007 & 0.0962 & 0.0303 & \\
\hline 20 & Takur tenggeret & Blue-eared Barbet & Megalaima australis & Megalaimidae & 12 & 4 & 0.0008 & 0.1025 & 0.0322 & \\
\hline 21 & Takur tutut & Red-crowned Barbet & Megalaima rafflesii & Megalaimidae & 22 & 7.333 & 0.0028 & 0.1557 & 0.0490 & 4.6656 \\
\hline 22 & Tekukur biasa & Spotted Dove & Streptopelia chinensis & Columbidae & 9 & 3 & 0.0005 & 0.0831 & 0.0261 & \\
\hline 23 & Tepus kaban & Black-throated Babbler & Stachyris nigricollis & Timaliidae & 7 & 2.333 & 0.0003 & 0.0689 & 0.0217 & \\
\hline 24 & Wiwik kelabu & Plaintive Cuckoo & Cacomantis merulinus & Cuculidae & 12 & 4 & 0.0008 & 0.1025 & 0.0322 & \\
\hline \multicolumn{3}{|c|}{ Jumlah } & & & 415 & 138.333 & 0.0740 & 2.8659 & 0.9018 & \\
\hline
\end{tabular}

Keterangan: ni= Jumlah individu, $\mathrm{C}=$ Dominasi, $\mathrm{H}=$ Keanekaragaman, $\mathrm{E}=$ Kemerataan, $\mathrm{R}=$ Kekayaan 
Tabel 3. Daftar jenis burung yang terdapat pada jalur kedua dengan 3 kali pengulangan (List of bird species found in the second route with 3 repetitions)

\begin{tabular}{|c|c|c|c|c|c|c|c|c|c|c|}
\hline No & Nama Indonesia & $\begin{array}{c}\text { Nama } \\
\text { Inggris }\end{array}$ & Nama Latin & Family & ni & $x^{-}$ & $\mathbf{C}$ & $\overline{\boldsymbol{H}}$ & $\mathbf{E}$ & $\mathbf{R}$ \\
\hline 1 & Asi topi-sisik & Scaly-crowned Babbler & Malacopteron cinereum & Timaliidae & 15 & 5 & 0.0020 & 0.1388 & 0.0456 & 4.2386 \\
\hline 2 & Bubut besar & Greater Coucal & Centropus sinensis & Cuculidae & 5 & 1.667 & 0.0002 & 0.0626 & 0.0206 & \\
\hline 3 & Burung-madu belukar & Ruby-cheeked Sunbird & Chalcoparia singalensis & Nectariniidae & 10 & 3.333 & 0.0009 & 0.1046 & 0.0344 & \\
\hline 4 & Burung-madu polos & Plain Sunbird & Anthreptes simplex & Nectariniidae & 23 & 7.667 & 0.0047 & 0.1836 & 0.0603 & \\
\hline 5 & Burung-madu sepah-raja & Eastern Crimson Sunbird & Aethopyga siparaja & Nectariniidae & 15 & 5 & 0.0020 & 0.1388 & 0.0456 & \\
\hline 6 & Cabai bunga-api & Orange-bellied Flowerpecker & Dicaeum trigonostigma & Dicaeidae & 22 & 7.333 & 0.0043 & 0.1785 & 0.0586 & \\
\hline 7 & Cinenen kelabu & Red-headed Tailorbird & Orthotomus ruficeps & Cisticolidae & 7 & 2.333 & 0.0004 & 0.0807 & 0.0265 & \\
\hline 8 & Cinenen belukar & Dark-necked Tailorbird & Orthotomus atrogularis & Cisticolidae & 7 & 2.333 & 0.0004 & 0.0807 & 0.0265 & \\
\hline 9 & Cinenen merah & Rufous-tailed Tailorbird & Orthotomus sericeus & Cisticolidae & 33 & 11 & 0.0096 & 0.2279 & 0.0749 & \\
\hline 10 & Cipoh kacat & Common Iora & Aegithina tiphia & Aegithinidae & 6 & 2 & 0.0003 & 0.0719 & 0.0236 & 4.2386 \\
\hline 11 & Delimukan zamrud & Emerald Dove & Chalcophaps indica & Columbidae & 7 & 2.333 & 0.0004 & 0.0807 & 0.0265 & \\
\hline 12 & Merbah cerukcuk & Yellow-vented Bulbul & Pycnonotus goiavier & Pycnonotidae & 61 & 20.333 & 0.0330 & 0.3098 & 0.1017 & \\
\hline 13 & Merbah mata-merah & Red-eyed Bulbul & Pycnonotus brunneus & Pycnonotidae & 46 & 15.333 & 0.0187 & 0.2722 & 0.0894 & \\
\hline 14 & Pijantung besar & Long-billed Spiderhunter & Arachnothera robusta & Nectariniidae & 6 & 2 & 0.0003 & 0.0719 & 0.0236 & \\
\hline 15 & Pijantung Kecil & Little Spiderhunter & Arachnothera longirostra & Nectariniidae & 29 & 9.667 & 0.0074 & 0.1388 & 0.0695 & \\
\hline 16 & Sempur-hujan darat & Black-and-yellow Broadbill & Eurylaimus ochromalus & Eurylaimidae & 9 & 3 & 0.0007 & 0.0626 & 0.0318 & \\
\hline 17 & Takur tenggeret & Blue-eared Barbet & Megalaima australis & Megalaimidae & 6 & 2 & 0.0003 & 0.2114 & 0.0236 & \\
\hline 18 & Takur tutut & Red-crowned Barbet & Megalaima rafflesii & Megalaimidae & 6 & 2 & 0.0003 & 0.0970 & 0.0236 & \\
\hline 19 & Tekukur biasa & Spotted Dove & Streptopelia chinensis & Columbidae & 7 & 2.333 & 0.0004 & 0.0719 & 0.0265 & \\
\hline 20 & Tepus kaban & Black-throated Babbler & Stachyris nigricollis & Timaliidae & 7 & 2.333 & 0.0004 & 0.0719 & 0.0265 & \\
\hline 21 & Wiwik kelabu & Plaintive Cuckoo & Cacomantis merulinus & Cuculidae & 9 & 3 & 0.0007 & 0.0807 & 0.0318 & 4.2386 \\
\hline \multicolumn{5}{|c|}{ Jumlah } & 336 & 112 & $\mathbf{0 . 0 8 7 7}$ & 2.7129 & 0.8911 & \\
\hline
\end{tabular}

Keterangan: ni= Jumlah individu, $\mathrm{C}=$ Dominasi, $\mathrm{H}=$ Keanekaragaman, $\mathrm{E}=$ Kemerataan, $\mathrm{R}=$ Kekayaan 
Tabel 4. Daftar jenis burung yang terdapat pada jalur ketiga dengan 3 kali pengulangan (List of bird species found in the third line with 3 repetitions)

\begin{tabular}{|c|c|c|c|c|c|c|c|c|c|c|}
\hline No & Nama Indonesia & Nama Inggris & Nama Latin & Family & ni & $x^{-}$ & $\mathbf{C}$ & $\overline{\boldsymbol{H}}$ & $\mathbf{E}$ & $\mathbf{R}$ \\
\hline 1 & Asi topi-sisik & Scaly-crowned Babbler & Malacopteron cinereum & Timaliidae & 25 & 8.333 & 0.0070 & 0.2079 & 0.0694 & 4.1318 \\
\hline 2 & Bondol Kalimantan & Dusky Munia & Lonchura fuscans & Estrildidae & 34 & 11.333 & 0.0130 & 0.2477 & 0.0827 & \\
\hline 3 & Bubut besar & Greater Coucal & Centropus sinensis & Cuculidae & 12 & 4 & 0.0016 & 0.1293 & 0.0432 & \\
\hline 4 & Burung-gereja erasia & Eurasian Tree Sparrow & Passer montanus & Passeridae & 26 & 8.667 & 0.0076 & 0.2128 & 0.0710 & \\
\hline 5 & Burung-madu belukar & Ruby-cheeked Sunbird & Chalcoparia singalensis & Nectariniidae & 11 & 3.667 & 0.0014 & 0.1218 & 0.0407 & 4.1318 \\
\hline 6 & Burung-madu polos & Plain Sunbird & Anthreptes simplex & Nectariniidae & 27 & 9 & 0.0082 & 0.2176 & 0.0726 & \\
\hline 7 & Burung-madu sepah-raja & Eastern Crimson Sunbird & Aethopyga siparaja & Nectariniidae & 3 & 1 & 0.0001 & 0.0463 & 0.0155 & \\
\hline 8 & Cabai bunga-api & Orange-bellied Flowerpecker & Dicaeum trigonostigma & Dicaeidae & 9 & 3 & 0.0009 & 0.1057 & 0.0353 & 4.1318 \\
\hline 9 & Cinenen belukar & Dark-necked Tailorbird & Orthotomus atrogularis & Cisticolidae & 10 & 3.333 & 0.0011 & 0.1139 & 0.0380 & \\
\hline 10 & Cinenen merah & Rufous-tailed Tailorbird & Orthotomus sericeus & Cisticolidae & 19 & 6.333 & 0.0041 & 0.1755 & 0.0586 & \\
\hline 11 & Cipoh kacat & Common Iora & Aegithina tiphia & Aegithinidae & 2 & 0.667 & 0.0000 & 0.0336 & 0.0112 & \\
\hline 12 & Delimukan zamrud & Emerald Dove & Chalcophaps indica & Columbidae & 10 & 3.333 & 0.0011 & 0.1139 & 0.0380 & \\
\hline 13 & Merbah cerukcuk & Yellow-vented Bulbul & Pycnonotus goiavier & Pycnonotidae & 42 & 14 & 0.0199 & 0.2762 & 0.0922 & \\
\hline 14 & Merbah mata-merah & Red-eyed Bulbul & Pycnonotus brunneus & Pycnonotidae & 30 & 10 & 0.0101 & 0.2311 & 0.0772 & \\
\hline 15 & Pijantung besar & Long-billed Spiderhunter & Arachnothera robusta & Nectariniidae & 3 & 1 & 0.0001 & 0.0463 & 0.0155 & 4.1318 \\
\hline 16 & Pijantung Kecil & Little Spiderhunter & Arachnothera longirostra & Nectariniidae & 13 & 4.333 & 0.0019 & 0.1366 & 0.0456 & \\
\hline 17 & Takur tutut & Red-crowned Barbet & Megalaima rafflesii & Megalaimidae & 2 & 0.667 & 0.0000 & 0.0336 & 0.0112 & \\
\hline 18 & Tekukur biasa & Spotted Dove & Streptopelia chinensis & Columbidae & 2 & 0.667 & 0.0000 & 0.0336 & 0.0112 & \\
\hline 19 & Tepus kaban & Black-throated Babbler & Stachyris nigricollis & Timaliidae & 8 & 2.667 & 0.0007 & 0.0971 & 0.0324 & 4.1318 \\
\hline 20 & Wiwik kelabu & Plaintive Cuckoo & Cacomantis merulinus & Cuculidae & 10 & 3.333 & 0.0011 & 0.1139 & 0.0380 & \\
\hline \multicolumn{3}{|c|}{ Jumlah } & & & 298 & 99.333 & 0.0802 & 2.6944 & 0.8994 & \\
\hline
\end{tabular}

Keterangan: ni= Jumlah individu, $\mathrm{C}=$ Dominasi, $\mathrm{H}=$ Keanekaragaman, $\mathrm{E}=$ Kemerataan, $\mathrm{R}=$ Kekayaan 
Tabel 5. Daftar jenis burung yang terdapat pada jalur keempat dengan 3 kali pengulangan (List of bird species found in the fourth whit 3 repetitions)

\begin{tabular}{|c|c|c|c|c|c|c|c|c|c|c|}
\hline No & Nama Indonesia & Nama Inggris & Nama Latin & Family & ni & $x^{-}$ & $\mathbf{C}$ & $\overline{\boldsymbol{H}}$ & $\mathbf{E}$ & $\mathbf{R}$ \\
\hline 1 & Asi topi-sisik & Scaly-crowned Babbler & Malacopteron cinereum & Timaliidae & 7 & 2.333 & 0.0007 & 0.0981 & 0.0318 & 4.4504 \\
\hline 2 & Bubut besar & Greater Coucal & Centropus sinensis & Cuculidae & 2 & 0.667 & 0.0001 & 0.0378 & 0.0122 & \\
\hline 3 & Burung-madu belukar & Ruby-cheeked Sunbird & Chalcoparia singalensis & Nectariniidae & 21 & 7 & 0.0067 & 0.2047 & 0.0662 & \\
\hline 4 & Burung-madu polos & Plain Sunbird & Anthreptes simplex & Nectariniidae & 29 & 9.667 & 0.0127 & 0.2462 & 0.0796 & \\
\hline 5 & Burung-madu sepah-raja & Eastern Crimson Sunbird & Aethopyga siparaja & Nectariniidae & 10 & 3.333 & 0.0015 & 0.1263 & 0.0409 & \\
\hline 6 & Cabai bunga-api & Orange-bellied Flowerpecker & Dicaeum trigonostigma & Dicaeidae & 8 & 2.667 & 0.0010 & 0.1080 & 0.0349 & 4.4504 \\
\hline 7 & Cinenen kelabu & Red-headed Tailorbird & Orthotomus ruficeps & Cisticolidae & 8 & 2.667 & 0.0010 & 0.1080 & 0.0349 & \\
\hline 8 & Cinenen belukar & Dark-necked Tailorbird & Orthotomus atrogularis & Cisticolidae & 8 & 2.667 & 0.0010 & 0.1080 & 0.0349 & \\
\hline 9 & Cinenen merah & Rufous-tailed Tailorbird & Orthotomus sericeus & Cisticolidae & 24 & 8 & 0.0087 & 0.2214 & 0.0716 & \\
\hline 10 & Cipoh kacat & Common Iora & Aegithina tiphia & Aegithinidae & 4 & 1.333 & 0.0002 & 0.0648 & 0.0210 & \\
\hline 11 & Delimukan zamrud & Emerald Dove & Chalcophaps indica & Columbidae & 4 & 1.333 & 0.0002 & 0.0648 & 0.0210 & \\
\hline 12 & Merbah cerukcuk & Yellow-vented Bulbul & Pycnonotus goiavier & Pycnonotidae & 29 & 9.667 & 0.0127 & 0.2462 & 0.0796 & \\
\hline 13 & Merbah mata-merah & Red-eyed Bulbul & Pycnonotus brunneus & Pycnonotidae & 36 & 12 & 0.0196 & 0.2753 & 0.0891 & \\
\hline 14 & Pelatuk Kelabu-Sulawesi & Ashy Woodpecker & Mulleripicus fulvus & Picidae & 1 & 0.333 & 0.0000 & 0.0216 & 0.0070 & \\
\hline 15 & Pijantung besar & Long-billed Spiderhunter & Arachnothera robusta & Nectariniidae & 5 & 1.667 & 0.0004 & 0.0766 & 0.0248 & \\
\hline 16 & Pijantung Kecil & Little Spiderhunter & Arachnothera longirostra & Nectariniidae & 18 & 6 & 0.0049 & 0.1862 & 0.0602 & \\
\hline 17 & Sempur-hujan darat & Black-and-yellow Broadbill & Eurylaimus ochromalus & Eurylaimidae & 13 & 4.333 & 0.0026 & 0.1509 & 0.0488 & \\
\hline 18 & Takur tenggeret & Blue-eared Barbet & Megalaima australis & Megalaimidae & 3 & 1 & 0.0001 & 0.0520 & 0.0168 & \\
\hline 19 & Takur tutut & Red-crowned Barbet & Megalaima rafflesii & Megalaimidae & 5 & 1.667 & 0.0004 & 0.0766 & 0.0248 & \\
\hline 20 & Tekukur biasa & Spotted Dove & Streptopelia chinensis & Columbidae & 6 & 2 & 0.0005 & 0.0877 & 0.0284 & 4.4504 \\
\hline 21 & Tepus kaban & Black-throated Babbler & Stachyris nigricollis & Timaliidae & 6 & 2 & 0.0005 & 0.0877 & 0.0284 & \\
\hline \multirow[t]{2}{*}{22} & Wiwik kelabu & Plaintive Cuckoo & Cacomantis merulinus & Cuculidae & 10 & 3.333 & 0.0015 & 0.1263 & 0.0409 & 4.4504 \\
\hline & Jumlah & & & & 257 & 85.667 & 0.0772 & 2.7754 & 0.8979 & \\
\hline
\end{tabular}

Keterangan: $\mathrm{ni}=$ Jumlah individu, $\mathrm{C}=$ Dominasi, $\mathrm{H}=$ Keanekaragaman, $\mathrm{E}=$ Kemerataan, $\mathrm{R}=$ Kekayaan 